\title{
Genome Size Determinations for 33 Strains of Budding Bacteria
}

\author{
JUTTA KÖLBEL-BOELKE, RAINER GEBERS, * AND PETER HIRSCH \\ Institut für Allgemeine Mikrobiologie, Universität Kiel, D-2300 Kiel, Germany
}

\begin{abstract}
The genome sizes of 33 strains of budding bacteria were determined by deoxyribonucleic acid renaturation kinetics. The $M_{r}$ values ranged from $1.67 \times 10^{9}$ to $4.43 \times 10^{9}$ for strains representing the following genera: Hyphomicrobium (seven strains; $M_{\mathrm{r}}, 2.08 \times 10^{9}$ to $2.73 \times 10^{9}$ ), Hyphomonas (six strains; $M_{\mathrm{r}}, 1.67 \times 10^{9}$ to 2.13 $\times 10^{9}$ ), Pedomicrobium (five strains; $M_{\mathrm{r}}, 2.81 \times 10^{9}$ to $3.43 \times 10^{9}$ ), genus T (two strains; $M_{\mathrm{r}}, 2.32 \times 10^{9}$ to 2.46 $\times 10^{9}$ ), genus D (one strain; $M_{\mathrm{r}}, 1.73 \times 10^{9}$ ), genus F (one strain; $M_{\mathrm{r}}, 2.03 \times 10^{9}$ ), Pirella (seven strains; $M_{\mathrm{r}}$, $2.73 \times 10^{9}$ to $4.43 \times 10^{9}$ ), and Planctomyces (four strains; $M_{\mathrm{r}}, 2.67 \times 10^{9}$ to $3.65 \times 10^{9}$ ). The taxa designated genus $\mathrm{T}$, genus $\mathrm{D}$, and genus $\mathrm{F}$ represented new budding bacteria which will be formally described elsewhere. The genome size ranges of Hyphomicrobium spp., Hyphomonas spp., and Pedomicrobium spp. were relatively small compared with those of Planctomyces spp. and Pirella spp. The plotting of genome sizes against deoxyribonucleic acid base compositions demonstrated distinct cluster areas, some of which allowed clear separation of the genera studied.
\end{abstract}

The budding bacteria are a little known, heterogeneous group of procaryotes with unclear taxonomic relationships. Recently, a large number of new isolates has become available, and there is a need for clear separation of genera and a reliable method of identifying possible new taxa.

Genome size has been described as a characteristic property of bacterial genera or species $(9,14)$. High precision and easy protocols for deoxyribonucleic acid (DNA) renaturation kinetic experiments $(3,4,8,22,24,25)$ have allowed serial determination of the genome sizes of numerous bacteria $(9,21,23)$. In the case of hyphal, budding bacteria, genome sizes have been determined previously for only two strains, Hyphomicrobium sp. strain B-522 $\left(M_{\mathrm{r}}, 3.1 \times 10^{9}\right)$ (17) and Rhodomicrobium vannielii RM5 $\left(M_{\mathrm{r}}, 2.1 \times 10^{9}\right)$ (20). In the present study renaturation experiments were carried out with 33 strains, most of which were classified as belonging to the genera Hyphomicrobium, Hyphomonas, Pedomicrobium, Planctomyces, and Pirella. Some other strains investigated in this study were morphologically and physiologically unlike any of the aforementioned genera and probably represent new taxa.

The data obtained for the 33 strains showed genome $M_{\mathrm{r}}$ values that ranged from $1.67 \times 10^{9}$ to $4.43 \times 10^{9}$. There were distinct clusters of morphologically similar organisms, which indicated the potential of using genome size determinations for separation of taxa.

\section{MATERIALS AND METHODS}

Strains and cultivation. The bacterial strains which we studied are listed in Table 1 . The sources of isolation and the culture conditions used are described in the accompanying paper (7).

Harvesting. Growth was followed by measuring turbidity at $670 \mathrm{~nm}$. Cultures in the stationary growth phase $(9,22)$ were checked for purity by phase-contrast microscopy and by plating onto solidified growth media and nutrient agar (Difco Laboratories, Detroit, Mich.) supplemented with $10 \mathrm{~g}$ of glucose per liter. Cells were pelleted by centrifugation at $16,000 \times g$ for $20 \mathrm{~min}$ at $4^{\circ} \mathrm{C}$ and washed twice in doubledistilled water or in a $0.85 \% \mathrm{NaCl}$ solution. The final pellets were stored at $-20^{\circ} \mathrm{C}$.

DNA preparation. The methods used for cell wall disinte-

\footnotetext{
* Corresponding author.
}

gration and DNA extraction are described in the accompanying paper (7). Cells of strain 1128 were pretreated five times $(2 \mathrm{~s}$ each) in an Ultra Turrax homogenizer (Jahnke and Kunkel, Staufen, Federal Republic of Germany) and then disrupted mechanically.

All purified DNAs except strain 954 DNA exhibited ratios of absorbance at $260 \mathrm{~nm}$ to absorbance at $230 \mathrm{~nm}$ to absorbance at $280 \mathrm{~nm}$ of 1:0.470:0.520; strain 954 DNA exhibited a ratio of 1:0.490:0.530.

All DNAs were dissolved in standard saline citrate $(1 \times$ $\mathrm{SSC}, 0.15 \mathrm{M} \mathrm{NaCl}$ plus $0.015 \mathrm{M}$ trisodium citrate [pH 7] and sheared to an average double-stranded fragment $M_{\mathrm{r}}$ of 420,000 by passing them twice through a French pressure cell (Aminco, Silver Spring, Md.) at 165.5 MPa (6). Subsequently, DNA solutions were dialyzed three times for $10 \mathrm{~h}$ each time against $1 \times \mathrm{SSC}$ and then stored at $-20^{\circ} \mathrm{C}$.

Renaturation kinetics. DNA renaturation was followed by measuring absorbance changes $(3,9)$ in hermetically sealed thermocuvettes (Gilford, Düsseldorf, West Germany) attached to a Gilford model 250 spectrophotometer which was equipped with a thermoprogrammer and a reference compensator. When this system was used, corrections for volume expansion or for evaporation of solvents were unnecessary (5). Optimal conditions for DNA renaturation were achieved at sodium concentrations of $>0.39 \mathrm{M}$ (9). Since most of the strains had high DNA base ratios, thermal denaturation of the DNAs had to be carried out in the presence of formamide, which reduced the melting temperature sufficiently. Therefore, we used $5 \times \mathrm{SSC}$ buffer $\left(\mathrm{Na}^{+}\right.$ concentration, $0.975 \mathrm{M})$ which contained $25 \%(\mathrm{vol} / \mathrm{vol})$ formamide ( $99 \%$ pure; Serva, Heidelberg, Federal Republic of Germany), a system appropriate for both denaturation and renaturation. Under our conditions, formamide lowered the midpoints of the DNA melting profiles in $5 \times \mathrm{SSC}$ by $0.75^{\circ} \mathrm{C}$ for each $1 \mathrm{~mol} \%$ guanine plus cytosine. However, renaturation reactions had to be followed at $270 \mathrm{~nm}$ instead of $260 \mathrm{~nm}$ (15). At this wavelength DNA absorption was still $80 \%$ of the absorption at $260 \mathrm{~nm}$.

Before renaturation, the DNAs were denatured by heating the solutions for $10 \mathrm{~min}$ at $10^{\circ} \mathrm{C}$ above the midpoint of the DNA melting profile in $5 \times$ SSC containing $25 \%$ formamide. The cuvettes were then cooled ( 3 to $4 \mathrm{~min}$ ) to the optimal renaturation temperature $\left(25^{\circ} \mathrm{C}\right.$ less than the midpoint of the DNA melting profile). This caused a rapid decrease in absorbancy (collapse hypochromicity), which resulted from 
TABLE 1. Genome sizes of appendaged or prosthecate, budding bacteria

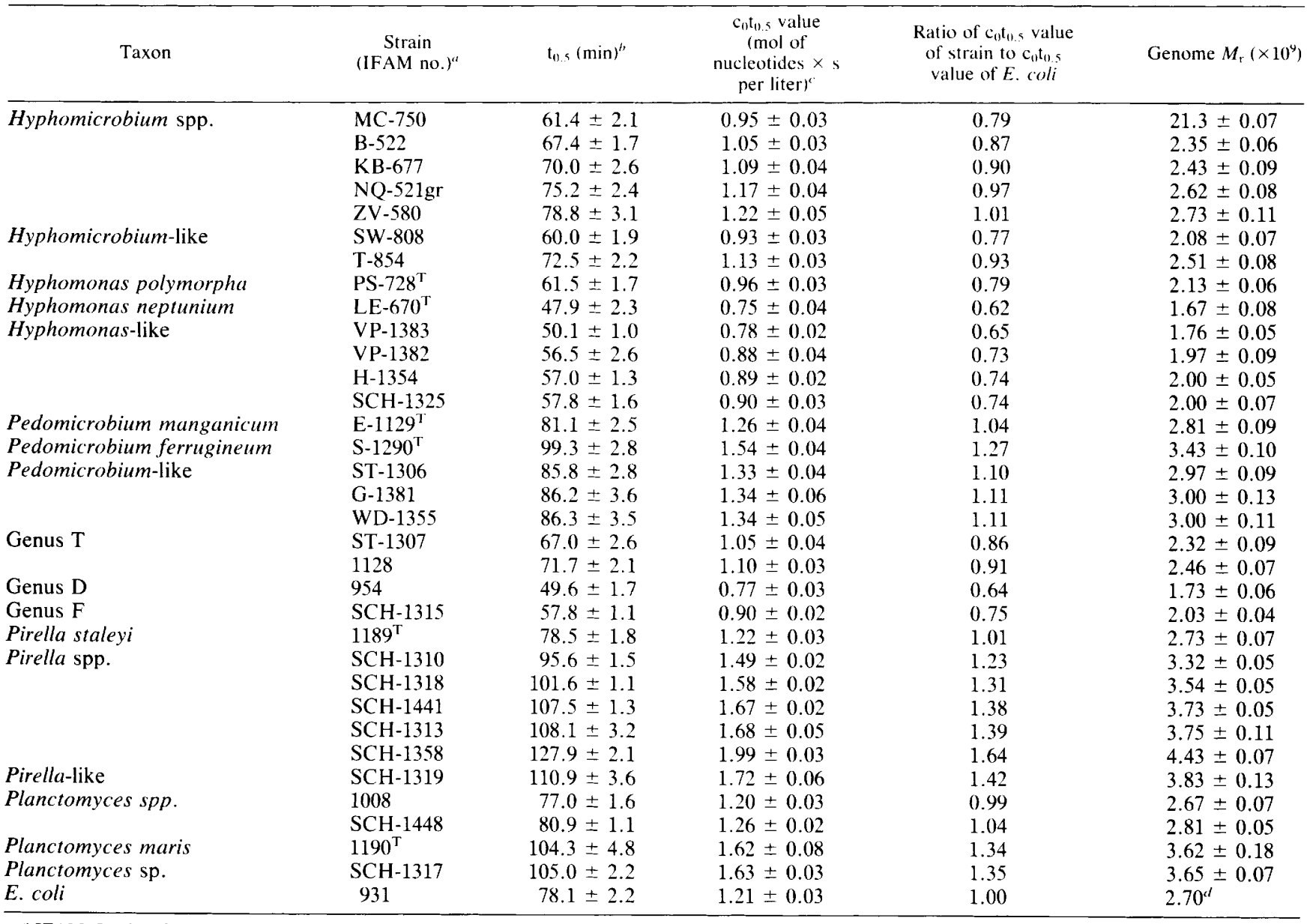

"IFAM, Institut für Allgemeine Mikrobiologie.

b Average of at least six determinations.

c The initial DNA concentration was $2.59 \times 10^{-4}$ mol of nucleotides per liter.

"Data from reference 11.

nonspecific base pairing within single-stranded DNA fragments (3). This collapse hypochromicity was excluded from the calculation of the $50 \%$ DNA renaturation time. Generally, we considered true renaturation to begin $5 \mathrm{~min}$ after the onset of cooling.

The DNAs were again denatured after each renaturation. The difference between the melting point of the denaturation mixture before renaturation and that after renaturation indicated the accuracy of the reaction, since $1 \%$ mismatched bases generally lowered the midpoint of the DNA melting profile of a renatured DNA by $1^{\circ} \mathrm{C}(1)$. The time of $50 \%$ renaturation $\left(\mathrm{t}_{0.5}\right)$ was determined from the absorbancy profiles recorded during the reaction; by multiplication with the initial DNA concentration $\left(c_{0}\right)$, the $c_{0} t_{0.5}$ value was calculated (4). The average molecular weight of a nucleotide was taken to be 309 (19). Bacterial DNAs exhibit an inverse proportionality of molecular complexity and renaturation velocity (4). Therefore, the genome size of a test DNA $(x)$ was calculated by using the following relationship: $c_{0} t_{0.5}$ $(x) / \mathrm{c}_{0} \mathrm{t}_{0.5}($ Escherichia coli $)=M_{\mathrm{r}}(x) / M_{\mathrm{r}}(E$. coli $)$. The $\mathrm{c}_{0} \mathrm{t}_{0.5}$ values were not corrected for differences between the DNA base compositions of the test strains and $E$. coli $(8,24)$. The molecular weight of $E$. coli $\mathrm{K}-12$ reference DNA was taken to be $2.7 \times 10^{9}(11)$.

\section{RESULTS}

The genome sizes of 33 strains selected from eight genera of budding bacteria are listed in Table 1. The genome molecular weights of these strains ranged from $1.67 \times 10^{9}$ to $4.43 \times 10^{9}$. Our data were not corrected for non-complementary base pairings, since the level of mismatching was less than $1 \%$ in all experiments. The position of each strain within the genome size range of its genus is shown in Fig. 1; strains having similar morphology were included in the same genus. Evidently, some genera were characterized by the sizes of their genomes and could be distinguished from each other because their genome size ranges did not overlap, as in the case of Hyphomonas and Pedomicrobium. On the other hand, the genome size ranges of Hyphomonas and Hyphomicrobium, as well as those of Planctomyces and Pirella, overlapped (Fig. 1), which correlated with the phenotypic similarities of these taxa (12).

\section{DISCUSSION}

Only a few genome sizes of budding bacteria have been reported previously. The Hyphomicrobium sp. strain B-522 genome was found by Moore and Hirsch (17) to have an $M_{\mathrm{r}}$ of $3.1 \times 10^{9}$. These authors obtained a ratio of strain B-522 


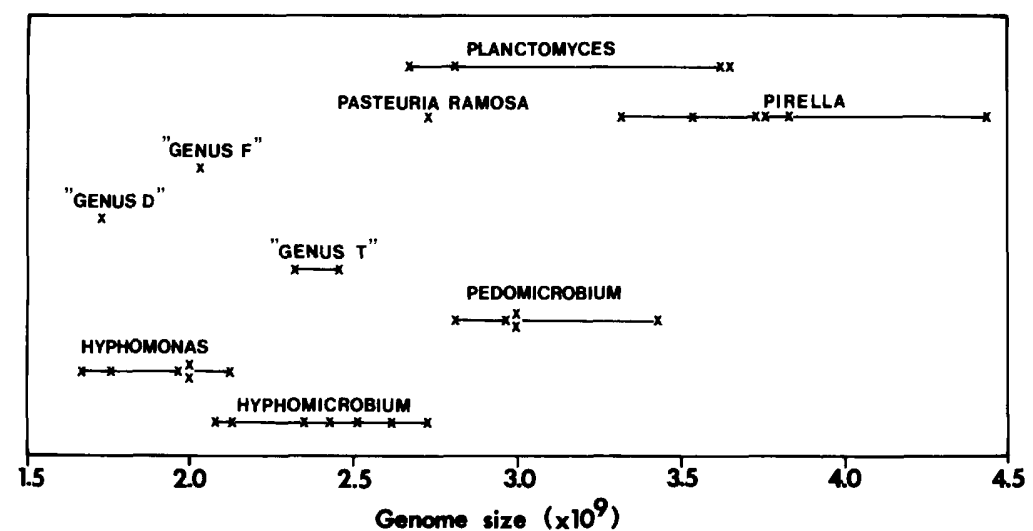

FIG. 1. Genome size ranges of budding bacteria. The taxa designated genus D, genus F, and genus $T$ represent new budding bacteria which have not been described thus far.

$\mathrm{c}_{0} \mathrm{t}_{0.5}$ value to $E$. coli $\mathrm{c}_{0} \mathrm{t}_{0.5}$ value of 0.83 ; our ratio of 0.87 agrees well with this value. However, our genome size value differs significantly from the value reported by Moore and Hirsch $\left(M_{\mathrm{r}}\right.$ of $2.35 \times 10^{9}$ compared with $M_{\mathrm{r}}$ of $\left.3.1 \times 10^{9}\right)(17)$. This difference can be explained as follows: (i) Moore and Hirsch assumed that the average molecular weight of a nucleotide pair was 660 , whereas we used a value of 618 (19). By multiplying the Cairn value of $4.5 \times 10^{6}$ nucleotide pairs for $E$. coli DNA by 660 , Moore and Hirsch based their calculation of strain B-522 genome size on an $M_{\mathrm{r}}$ value of $2.97 \times 10^{9}$ for the $E$. coli chromosome, whereas we used an $M_{\mathrm{r}}$ value of $2.70 \times 10^{9}$, a value which appeared to be more probable (11). (ii) A larger difference in the data resulted from the $\mathrm{c}_{0} \mathrm{t}_{0.5}$ value for $E$. coli DNA used by Moore and Hirsch (17); considering the " $10 \%$ difference in base composition of the two DNAs," these authors corrected the $\mathrm{c}_{0} \mathrm{t}_{0.5}$ value of $E$. coli DNA (2.90) "by a factor of 0.8 as indicated by the data of Wetmur and Davidson (25)." This reduced the $E$. coli $\mathrm{c}_{0} \mathrm{t}_{0.5}$ value to 2.32 , which resulted in a higher value for the Hyphomicrobium sp. strain B-522 genome size. More recently, Wetmur (24) and others (8) refrained from using correction factors for differences in DNA base composition. Since all discussions concerning this problem did not offer strong arguments for the necessity of such a correction, we avoided it. A new calculation of the data of Moore and Hirsch, in which an $M_{\mathrm{r}}$ value of $2.70 \times 10^{9}$ was used for the $E$. coli genome and no guanine-pluscytosine correction was used, gave an $M_{\mathrm{r}}$ value of $2.24 \times 10^{9}$ for the strain B-522 genome, which is close to our estimate $\left(M_{\mathrm{r}}, 2.35 \times 10^{9}\right)$.

The genome size of $R$. vannielii RM5 was determined previously by Potts et al. (20). These authors reported an $M_{\mathrm{r}}$ value of $2.1 \times 10^{9}$ for the DNA of this hyphal, budding bacterium. However, a recalculation of the $c_{0} t_{0.5}$ ratios of these authors (compared with $E$. coli DNA) gave $M_{\mathrm{r}}$ values of $1.81 \times 10^{9}$ to $1.98 \times 10^{9}$.

The genome sizes of other budding bacteria are not known at this time. Our values could be compared with those determined for other groups of bacteria. The genome molecular weights of 18 strains of $E$. coli were found to vary from $2.29 \times 10^{9}$ to $2.97 \times 10^{9}(2)$, and those of 13 Klebsiella pneumoniae strains ranged from $2.2 \times 10^{9}$ to $3.0 \times 10^{9}(21)$.

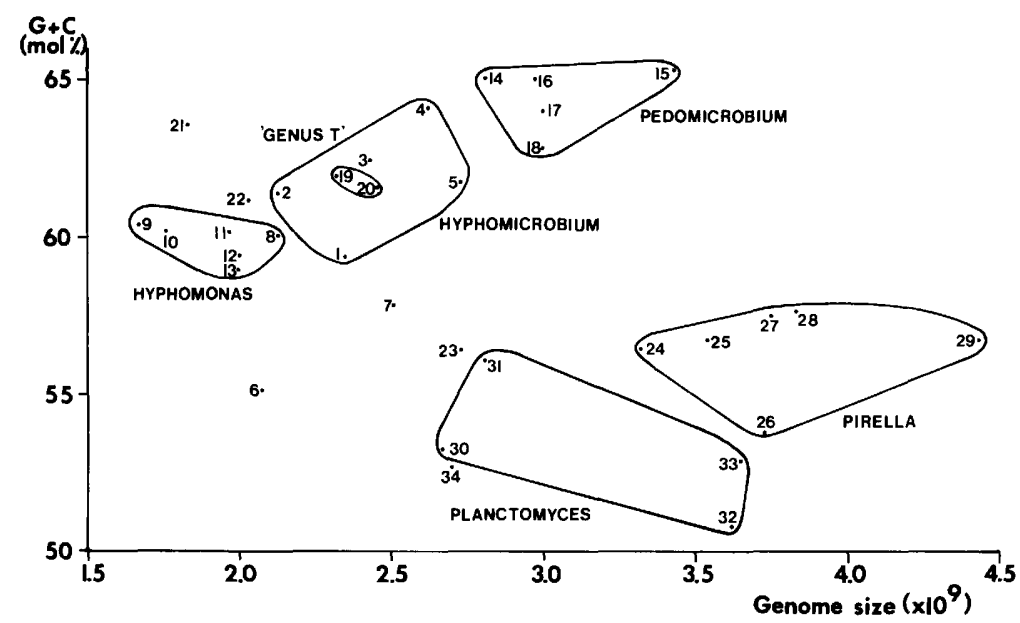

FIG. 2. Similarity of budding bacteria based on genome sizes and DNA base compositions. Solid lines encircle strains of the same genus. The numbers indicate the positions of strains, as follows: 1, strain MC-750; 2, strain B-522; 3, strain KB-677; 4, strain NQ-521gr; 5, strain ZV-580; 6, strain SW-808; 7, strain T-854; 8, strain PS-728 $; 9$, strain LE-670 $; 10$, strain VP-1383; 11, strain VP-1382; 12, strain H-1354; 13, strain SCH-1325; 14, strain E-1129 ${ }^{\mathrm{T}}$; 15, strain S-1290 $;$; 16, strain ST-1306; 17, strain G-1381; 18, strain WD-1355; 19, strain ST-1307; 20, strain 1128:, 21, strain 954; 22, strain SCH-1315; 23, strain $1189^{\mathrm{T}} ; 24$, strain SCH-1310; 25, strain SCH-1318; 26, strain SCH-1341; 27, strain SCH-1313; 28, strain SCH-1319; 29, strain SCH-1358; 30, strain 1008; 31, strain SCH-1448; 32, strain 1190 ${ }^{\mathrm{T}}$; 33, strain SCH-1317; 34, strain 931. G+C, Guanine-plus-cytosine content. 
These large ranges of variation within individual species were similar to the genome size differences which we found within genera (Hyphomicrobium $M_{\mathrm{r}}, 2.08 \times 10^{9}$ to $2.73 \times$ $10^{9}$; Hyphomonas $M_{\mathrm{r}}, 1.67 \times 10^{9}$ to $2.13 \times 10^{9}$; Pedomicrobium $M_{\mathrm{r}}, 2.81 \times 10^{9}$ to $\left.3.43 \times 10^{9}\right)$. The genome sizes of these budding bacteria may be more conserved characters than the genome sizes of members of the Enterobacteriaceae.

The usefulness of genome size values for taxonomic separation of budding bacteria became particularly evident when the data were plotted against the corresponding DNA base compositions (7) (Fig. 2).

The two-dimensional combination of genome sizes and DNA base ratios results in a clustering of related strains in distinct areas of a similarity map. Hyphomicrobium-like strains SW-808 and T-854 did not cluster with the other hyphomicrobia since their DNA base compositions differed significantly from those of all hyphomicrobia investigated so far. The similarity map allows taxonomists to deduce, from the distant positions of a pair of strains, their possibly distant relationship to each other; however, close positions may not necessarily reflect a close relationship. For example, strain LE- $670^{\mathrm{T}}$ ( $\mathrm{T}=$ type strain) was originally named "Hyphomicrobium neptunium" (13). On the map this strain was located at a considerable distance from the Hyphomicrobium region, which indicated only a faint relationship. The results of previous DNA-DNA hybridization studies (16), detailed comparisons with 82 hyphomicrobia (10), and recent DNADNA hybridizations (6a) suggested that strain LE-670 ${ }^{\mathrm{T}}$ would have to be transferred to the genus Hyphomonas (18). This was in good agreement with the position of this strain close to the Hyphomonas area (Fig. 2). On the other hand, morphological and physiological properties of genus $\mathrm{T}$ strains indicated little relationship with Hyphomicrobium spp., which could not be deduced from the data presented in Fig. 2.

\section{ACKNOWLEDGMENTS}

Part of this work was supported by a grant from the Deutsche Forschungsgemeinschaft, Bonn-Bad Godesberg, Federal Republic of Germany (to P.H.).

\section{LITERATURE CITED}

1. Bautz, E. K. F., and F. A. Bautz. 1964. The influence of non-complementary bases on the stability of ordered polynucleotides. Biochemistry 52:1476-1481.

2. Brenner, D. J., G. R. Fanning, F. J. Skerman, and S. Falkow. 1972. Polynucleotide sequence divergence among strains of Escherichia coli and closely related organisms. J. Bacteriol. 109:953-965.

3. Britten, R. J., D. E. Graham, and B. R. Neufeld. 1974. Analysis of repeating DNA sequences by reassociation. Methods Enzymol. 29:363-405.

4. Britten, R. J., and D. E. Kohne. 1968. Repeated sequences in DNA. Science 161:529-540.

5. Gebers, R., M. Mandel, and P. Hirsch. 1981. Deoxyribonucleic acid base composition and nucleotide distribution of Pedomicrobium spp. Zentralbl. Bakteriol. Parasitenkd. Infektionskr. Hyg. Abt. 1 Orig. Reihe C 2:332-338.

6. Gebers, R., R. L. Moore, and P. Hirsch. 1981. DNA-DNA reassociation studies on the genus Pedomicrobium. FEMS Microbiol. Lett. 11:283-286.

6a.Gebers, R., R. L. Moore, and P. Hirsch. 1984. Physiological properties and DNA-DNA homologies of Hyphomonas polymorpha and Hyphomonas neptunium. Syst. Appl'. Microbiol. 5:510-517.

7. Gebers, R., U. Wehmeyer, T. Roggentin, H. Schlesner, J; Kölbel-Boelke, and P. Hirsch. 1985. Deoxyribonucleic acid base compositions and nucleotide distributions of 65 strains of budding bacteria. Int. J. Syst. Bacteriol. 35:260-269.

8. Gillis, M., and J. De Ley. 1975. Determination of the molecular complexity of double-stranded phage genome DNA from initial renaturation rates. The effect of DNA base composition. J. Mol. Biol. 98:447-464

9. Gillis, M., J. De Ley, and M. De Cleene. 1970. The determination of molecular weight of bacterial genome DNA from renaturation rates. Eur. J. Biochem. 12:143-153.

10. Hirsch, P. 1974. Genus Hyphomicrobium Stutzer et Hartleb, 1898, p. 148-150. In R. E. Buchanan and N. E. Gibbons (ed.), Bergey's manual of determinative bacteriology, 8th ed. The Williams \& Wilkins Co., Baltimore.

11. Klotz, L. C., and B. H. Zimm. 1972. Size of DNA determined by viscoelastic measurements: results on bacteriophages, Bacillus subtilis and Escherichia coli. J. Mol. Biol. 72:779-800.

12. König, E., H. Schlesner, and P. Hirsch. 1984. Cell wall studies on budding bacteria of the Planctomyces/Pasteuria group and on a Prosthecomicrobium sp. Arch. Microbiol. 138:200-205.

13. Leifson, E. 1964. Hyphomicrobium neptunium $s p$. $n$. Antonie van Leeuwenhoek J. Microbiol. Serol. 30:249-256.

14. Mandel, M. 1969. New approaches to bacterial taxonomy: perspective and prospects. Annu. Rev. Microbiol. 23:239-274.

15. McConaughy, B. L., C. D. Laird, and B. J. McCarthy. 1969. Nucleic acid renaturation in formamide. Biochemistry 8:32893295 .

16. Moore, R. L., and P. Hirsch. 1972. Deoxyribonucleic acid base sequence homologies of some budding and prosthecate bacteria. J. Bacteriol. 110:256-261.

17. Moore, R. L., and P. Hirsch. 1973. Nuclear apparatus of Hyphomicrobium. J. Bacteriol. 116:1447-1455.

18. Moore, R. L., R. M. Weiner, and R. Gebers. 1984. Genus Hyphomonas Pongratz 1957 nom. rev. emend., Hyphomonas polymorpha Pongratz 1957 nom. rev. emend., and Hyphomonas neptunium (Leifson 1964) comb. nov. emend. (Hyphomicrobium neptunium). Int. J. Syst. Bacteriol. 34:71-73.

19. Park, I. W., and J. De Ley. 1967. Ancestral remnants in deoxyribonucleic acid from Pseudomonas and Xanthomonas. Antonie van Leeuwenhoek J. Microbiol. Serol. 33:1-16.

20. Potts, L. E., C. S. Dow, and R. J. Avery. 1980. The genome of Rhodomicrobium vannielii, a polymorphic prosthecate bacterium. J. Gen. Microbiol. 117:501-507.

21. Seidler, R. J., M. D. Knittel, and C. Brown. 1975. Potential pathogens in the environment: cultural reaction and nucleic acid studies on Klebsiella pneumoniae from clinical and environmental sources. Appl. Microbiol. 29:819-825.

22. Seidler, R. J., and M. Mandel. 1971. Quantitative aspects of deoxyribonucleic acid renaturation: base composition, state of chromosome replication and polynucleotide homologies. J. Bacteriol. 106:608-614.

23. Seidler, R. J., M. Mandel, and J. N. Baptist. 1972. Molecular heterogeneity of the bdellovibrios: evidence of two new species. J. Bacteriol. 109:209-217.

24. Wetmur, J. G. 1976. Hybridization and renaturation kinetics of nucleic acids. Annu. Rev. Biophys. Bioeng. 5:337-361.

25. Wetmur, J. G., and N. Davidson. 1969. Kinetics of renaturation of DNA. J. Mol. Biol. 31:349-370. 